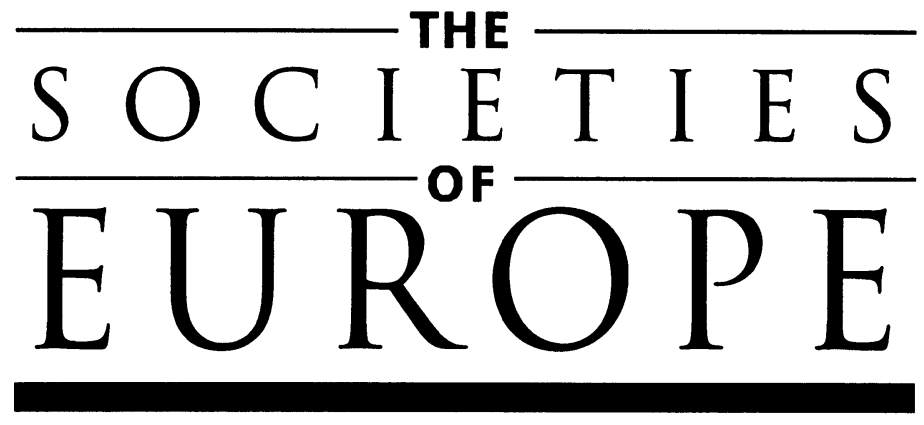

A series of historical data handbooks on the development of Europe from the nineteenth to the end of the twentieth century

Series Editors

Peter Flora, Franz Kraus, and Franz Rothenbacher

Elections in Western Europe since 1815 


\title{
THE SOCIETIES OF EUROPE
}

\author{
A series of publications by the \\ Mannheim Centre for European Social Research
}

Trade Unions in Western Europe since 1945

The European Population, 1850-1945

The European Population since 1945

The European Labour Force, 1870-1940

The European Labour Force since 1950

European Social Security Systems, 1885-1945

European Social Security Systems since 1945 


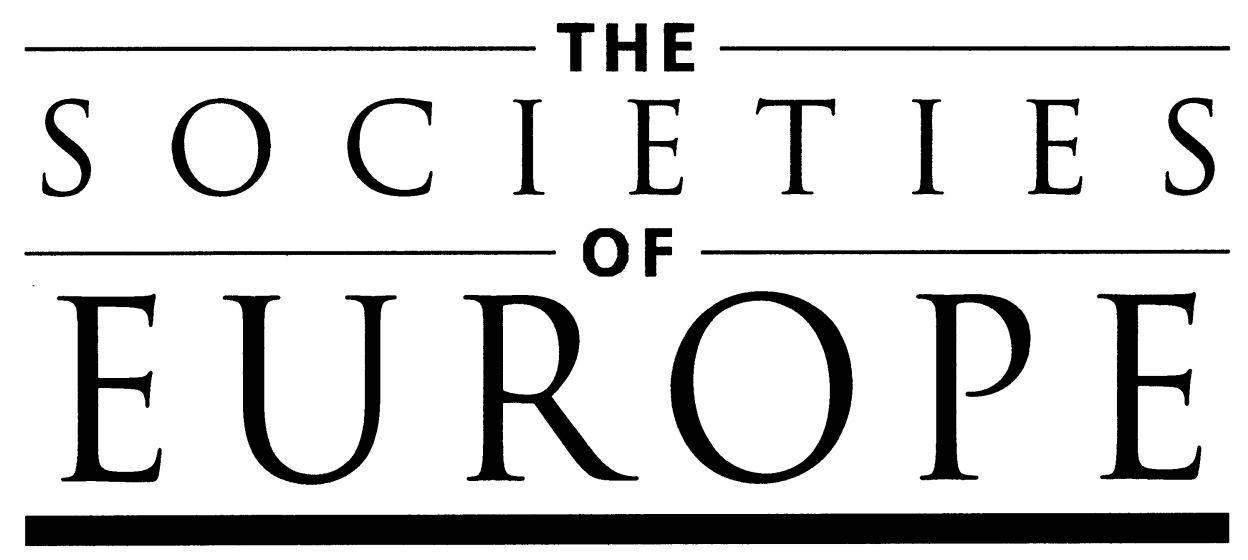

Elections in Western Europe since 1815

Electoral Results by Constituencies 
All rights reserved.

No part of this publication may be reproduced, stored in or introduced into a retrieval system, or transmitted, in any form or by any means (electronic, mechanical, photocopying, recording or otherwise) without prior written permission of the publisher unless in accordance with the provisions of the Copyright Designs and Patents Act 1988, or under the terms of any licence permitting limited copying issued by the Copyright Licensing Agency, 90 Tottenham Court Road, London W1P 9HE, UK.

Further, any person, company or firm found to be reproducing or assisting others in producing mailing lists, or machine-readable versions derived from this publication will be prosecuted for copyright infringement.

Published in the United States and Canada by GROVE'S DICTIONARIES, INC., 2000

345 Park Avenue South, 10th Floor, New York, NY 10010-1707

Grove's Dictionaries ISBN 978-1-56159-243-2

A catalog record for this book is available from the Library of Congress

Published in the United Kingdom by

MACMILLAN REFERENCE LTD, 2000

25 Eccleston Place, London SW1W 9NF

Basingstoke and Oxford

Companies and representatives throughout the world

British Library Cataloguing in Publication Data:

Caramani, Daniele

1. Elections - Europe - History - 19th century - Statistics

2. Elections - Europe - History -20 th century - Statistics

I. Title

$324.9^{\prime} 4^{\prime} 028$

ISBN 978-0-333-77-111-2 ISBN 978-1-349-65508-3 (eBook)

DOI 10.1007/978-1-349-65508-3

Distributed by Macmillan Distribution Ltd

Brunel Road, Houndmills, Basingstoke, Hants RG21 6XS

Visit our website: http://www.macmillan-reference.co.uk

Typeset by Mannheim Centre for European Social Research, Mannheim, Germany 


\section{Editorial Introduction The Unity and Diversity of Europe}

\section{by Peter Flora}

This handbook on European elections is the first in a whole series of volumes. With this series we hope to improve the empirical basis for a comparative-historical analysis of the Societies of Europe which is also the title chosen for the series.

\section{Unity and diversity}

Anyone who is interested in Europe, as a citizen or scientist, faces the basic question of the unity and diversity of the European societies. The question itself is characteristic of Europe; for any other region of the world, it would make much less sense. Between unity and diversity, there has been a persistent though varying tension, with productive as well as destructive consequences. This tension was at the very heart of the unique dynamism of European society, of its modern achievements which have spread over the world; but it was also at the root of the unique destructiveness of the Europeans who made their civil wars into world wars.

'Diversity within unity', 'unity of diversity': questions behind such plays on words can only be studied meaningfully in a long-term historical perspective. What we call Europe today grew out of the decline of the Roman Empire which was centred on the Mediterranean, superimposed a strong military-administrative structure on the ethnic and cultural diversity of its peoples, and achieved a certain cultural integration through the Latin language, Roman law, and later the Christian religion.

With the breakdown of the Western empire as a political entity and with the Islamic conquests in North Africa and the Iberian peninsula, the centre of gravity shifted to the north-west, and ethnicity became a dominant principle of political organization. This meant increasing diversity. The fragmentation was counteracted, however, by the unifying impact of Western Christianity. The Roman Church had survived the political breakdown and was able to spread its influence over the centuries to the north and east, far beyond the former limes.

Through its centralized and bureaucratic structure, the Roman Church had a standardizing effect on the organization of social life across the continent, and through its reliance on canonical law it shaped the specific role law has played in European societies in general and for their social institutions in particular. Thus, the Europe we know today was created first of all as a cultural and legal entity.

Cultural unity, however, had to coexist with political fragmentation. The attempt to resurrect the Roman Empire in the Carolingian empire and its successors ultimately failed. The German-Roman Empire never covered all of the then-important territories of Europe, and in the long run its internal structure proved too weak. But nevertheless it kept the idea of a politically-unified Europe alive. 
The failures of empire-building cleared the way for the development of the modern state with a more compact territory, more clearly-defined boundaries, a more differentiated centre, and closer relationships between centre and territorial population. With these developments, though they varied across time and space, European diversity acquired a clear political gestalt: it became a system of territorial states.

A new map of political boundaries was drawn, overlaying the much older map of ethnic-linguistic boundaries which had been the result of successive waves of migration over the centuries. The concurrence or discrepancy of these two types of boundaries set the options for the later transformation of the territorial into national states. These conditions greatly varied across Europe, and in general ethnic heterogeneity increased from the west (and north) to the east. Thus, for a long time Europe was divided between Western European nation-states and Eastern European multi-ethnic empires, with the rather different, confederated and consociational political structures of Central Europe in between.

The development of the European nation-state as the predominant form of political organization was closely linked to the earlier rise of vernaculars to languages with written standards and a corresponding decline of Latin as the means of elite communication. It was also facilitated by the establishment of national Protestant churches in northern Europe, as a consequence of the Reformation, whereas the Catholic Church retained its supra-national character. The division of Western Christianity also produced a new map which, as in the case of ethnic-linguistic boundaries, did not always coincide with the political map.

In this way, the diversity of Europe assumed a new shape: it became a diversity of varying relationships between political organization on the one hand and cultural, above all linguistic and religious, heterogeneity or homogeneity on the other. This kind of diversity was rooted in the past, but it developed in full only with the fundamental transformation of European societies since the nineteenth century: with industrialization and urbanization, with the creation of national systems of mass education, and with the democratization of the political systems. Europe became a system of nation-states and reached the highest degree of fragmentation in its history, hardly contained within a common cultural frame.

The democratization of the European nation-states and their transformation into welfare states added two new dimensions to the diversity of Europe: the diversity of public institutions and the diversity of intermediary structures. New institutions were created in the search for national solutions to problems and tasks connected with the development of capitalist industrial societies: not only systems for mass education, but also for social security, for health, and for other areas relevant for the life chances and living conditions of the mass population. And these institutions have greatly varied in many respects, above all in the degree of their 'stateness' as well as in the extent of their fragmentation or unity.

This institutional diversity across Europe largely persists today, as does the diversity of intermediary structures. In the process of democratization, older and newer cleavages dividing the people of the nation-states were transformed into a variety of 'intermediary' organizations: political parties, trade unions, co-operatives, voluntary welfare organizations and many others. Many of these organizations emerged from older cleavages resulting from the non-congruence of political and 
cultural boundaries. Others were related to new cleavages generated by the process of capitalist industrialization. As the structure of these cleavages has greatly varied across Europe, so have the intermediary structures.

In the process of industrialization, due to differences in its timing and character, economic diversity was increasing across Europe over a long period of time, and the continent became ever more structured into economic centres and peripheries. This was not a completely new diversity, however, but one that developed out of older divisions. There was, first, the old city belt stretching from Northern Italy to the Low Countries and across the Channel, a product of the revival and redirection of longdistance trade in medieval times. Industrialization added new towns and urban areas, but did not replace this dorsal spine of economic Europe with something completely new.

There was, second, the later rise of a mercantilist Atlantic capitalism which divided Europe roughly into an advanced economic centre in the north-west, a dependent periphery in the east, and a semi-periphery in the mediterranean south. The diffusion of the process of industrialization and the later rise of other regions such as Scandinavia have somewhat changed and also reduced economic diversity, but older divisions still reappear in the territorial structuring of the more advanced industrial as well as 'post-industrial' activities across Europe today.

\section{Dimensions of variation}

Putting together the elements mentioned above, one may try to define European diversity since the nineteenth century, the period covered by this series of handbooks, in the following way: it is first of all a diversity of societies politically organized as nation-states varying in at least three crucial dimensions:

1. the varying interrelations between political organization and cultural heterogeneity, as a result of the different political and cultural boundary-building in the processes of state formation and nation-building;

2. the variations in public institutions and intermediary organizations, as a result of the transformation of varying cleavage structures and state-society relationships in the processes of democratization and the building of welfare states;

3. the varying interrelations between the different positions of the national societies in the European world economy on the one hand, and the varying structuring of their internal division of labour on the other.

\section{Twentieth-century divisions}

On the eve of World War I, an observer might have gained the impression that the whole of Europe (except Russia and the Ottoman Empire) was on the road to democracy, that industrial capitalism would sooner or later shape the structure of all European societies, and that the European nations, although in fierce competition throughout the world, were somewhat held together not only by economic exchange, but also by a common belief in scientific and social progress.

History took another turn, as we know today. After the first great civil war of the Europeans in the twentieth century, democracy broke down in most of Central 
Europe, and it could not develop in the old South nor in the new nation-states of Central-Eastern Europe emerging from the breakdown of the eastern empires. This divided Europe deeply, between a democratic-liberal and a fascist-authoritarian part, building on existing and much older divisions. In addition, Europe was split even more radically by the Russian October Revolution which led not only to a new, totalitarian, political system, but also to a new form of non-capitalist industrial society. And this new political, economic, and social model was exported after the second great civil war, via the Red Army, to Central-Eastern Europe.

This meant that after 1945, the enfeebled Europe, stripped of its leading role in the world, became more divided than ever before in its history, and this for almost half a century until the breakdown of communism in Eastern Europe. Western Europe, however, increasingly identified with Europe itself, proved able to revive the ancient idea of European unity and to base it on common institutions. Ironically, with the liberation of Eastern Europe, a historical event pointing to the future, we seem to witness the reappearance of the basic and much older structure of Europe in its unity and diversity.

\section{'Core' and 'peripheries'}

The core of the (Western) European unification movement still lies in the territories of the old Carolingian empire and the old central city belt. The success of this core, above all in economic terms, and the not unrealistic hope of the other nations to use the increased strength of a more unified Europe for their own purposes explain the momentum European integration has gained. The success of the core was a precondition for the democratization and economic development of Southern Europe, and it may have the same beneficial effects in Eastern Europe, or at least parts of it.

The core territories have become the heart of European integration not because they have been homogeneous; quite the contrary. One might even say that their strength, beyond sheer demographic and economic weight, simply lies in the combination of a diversity typical of Europe, with roots reaching far back into history: to the limes and the great migrations which produced Romanic and Germanic territories with their ethnic and cultural differences; to the division of the Carolingian empire which ultimately led to the antithesis of a centralized French nation-state and a federated German empire with a delayed nation-building; and to the Lotharingian middle zone, the origin of the specific development of city states and confederations in Northern Italy and the Low Countries; and to the Reformation which cut across the whole area.

Around the West European 'core' we find territories that one may call 'peripheries', but for very different reasons. There are first of all the British Isles, only briefly and partially incorporated into the Roman Empire, never part of the German-Roman Empire, breaking with Rome and establishing a national church, building its own overseas empire, on the basis of a strong domestic society as the first industrial nation and with a long-standing democratic tradition. This explains the distance to Europe and much of the specificities of English society. With the loss of the empire and a certain move towards 'Europe' this may change but will certainly not disappear. 
The Iberian powers, Spain above all, shared with Britain the distance-creating experience of overseas empire-building, but their internal development was rather different. Absolutism and social rigidity set barriers to political modernization, social mobility, and economic innovation. This led to a long-lasting decline and to an isolation from 'Europe', overcome only more recently, and with enduring consequences for the social structure and institutions of the Iberian societies.

Scandinavia may be considered a third 'periphery' which also developed in relative isolation from 'Europe' and took an autonomous road. The early end of empire-building efforts and the successful political centralization of the home territories, the establishment of national Protestant churches, early nation-building, and the relatively high degree of freedom and equality traced out the way to mass democracy and welfare states. The Scandinavian countries were able to develop a specific model in which the state and the community of people do not fall apart and in which egalitarianism is writ large.

Moving to the 'peripheries' in eastern and south-eastern Europe, things become more complicated, because these territories are very heterogeneous in themselves and because there the question of the boundaries of Europe arises. The diversity has been of course one of ethnic-linguistic differences. But two other divisions have probably been even more important: the demarcation line between the Roman Catholic and the Greek Orthodox Church, and the partition of the area among the various multi-ethnic empires.

Europe was Christianized from two centres: from Rome, the fountainhead of Western Christendom, pushing to the north into Scandinavia, to the east into CentralEastern Europe, and also to the south-east; and from Byzantium, the centre of Eastern Christianity, moving through the Balkans into Moravia and Bohemia. Where they met, there was conflict. But around the year 1000 the question was settled, the territory partitioned: Poland, the Czech lands, Hungary and Croatia became Roman Catholic and largely remained so; Serbia, Bulgaria, and the Ukrainian and Russian territories became and stayed Orthodox. This line of division was to isolate these Slavic areas from cultural influences coming from the 'West'.

There were early and successful state-building efforts in all these areas, supported by the various 'national' orthodox churches, but also by the Roman Catholic Church in Poland and Hungary. Ultimately, however, they all failed, partly due to the invasions from Central Asia, partly as a consequence of relative economic decline and increasing dependence on the 'West'. Thus, they all became incorporated into multi-ethnic empires: into the absolutist Austrian, the autocratic Russian, and the despotic Ottoman empires.

The boundaries of these empires overlaid religious and ethnic boundaries, thus adding to the heterogeneity of the region. The character of these empires and varying lengths of their dominance were decisive in shaping the social structures and institutions of the various societies-and in setting the boundaries of Europe. The Habsburg empire was the leading German power and a stronghold of Catholicism. It was therefore able to draw its non-German and non-Catholic territories and people within the orbit of 'Europe'. The Ottoman empire, on the other hand, was clearly non-European, and the longer its dominance lasted in the Balkans, the less European these territories became. Turkey has special relations with Europe, but does not belong to it. 
Russia is a more complicated case. Long isolated from Western developments, it created an autocratic political system and hierarchical society unknown in 'Europe': and moving to east as well as to the west, it developed not only an empire but its own civilization, much as the Americans did, though of course in different form. To speak of a Europe from the Atlantic to the Urals is as meaningful as to define it as the area between Brest-Litovsk and San Francisco. Europe ends where Russia starts, and where Russia dominated over a long period, the boundaries become unclear.

When we started to plan the series of handbooks in the late 1980s, it still seemed natural to limit it to Western Europe. The revolutionary changes after 1989, however, have also changed our mental map. We have tried to extend the coverage of the series towards the east, but these attempts ran up against a variety of difficulties of language, data accessibility, availability of literature and more. Thus, our achievements fell short of our expectations. In some respects, of course, it would not have been meaningful to include Eastern Europe, because institutions and organizations such as free elections and free trade unions simply did not exist. In other respects such as population, labour force and social security, however, we usually have included Poland, the former Czechoslovakia, and Hungary, but other Eastern European countries much less systematically.

\section{Three developments and eight handbooks}

The coverage of the series is limited not only in terms of space, but also in terms of time and substance (see Synopsis 1). As to the substance, we have concentrated on various aspects of three major developments or growth processes since the nineteenth century: population growth and demographic transition; industrialization and the changing division of labour; democratization and the growth of welfare states. These developmental processes have shaped the social structures and institutions of the European societies for more than a century. For two or more decades, however, they have been approaching an end, and Europe seems to have entered a new historical phase of structural change and institutional adaptation in all three dimensions: family, employment, and social security.

From the mid-nineteenth century up to World War I, Europe was probably the region with the fastest-growing population in the world. But it was also the first to start the 'demographic transition' from high to low birth and death rates, with a first nadir in the 1930s and a second fall since the 1960s. This process was closely linked to changing family structures. (Western) Europe had been characterized for centuries by a specific marriage pattern with a high age at marriage and a high percentage of unmarried adults. This pattern started to change in the late nineteenth century, until marriage and the nuclear family had become almost universal in the 1950s. But then, from the 1960s, there was a radical turn with increasing marriage instability and family variety, and reforms in family law of historic dimensions.

Two volumes of the series are dedicated to population and family developments, one for the period from the nineteenth century to the Second World War, and the second for the time after 1945. Data included in the handbooks are limited to those available from the civil or ecclesiastical registers (mainly births, deaths, marriages, divorces) and from the population censuses (mainly population by age, sex, and civil status, later household composition), and for more recent times from microcensuses 


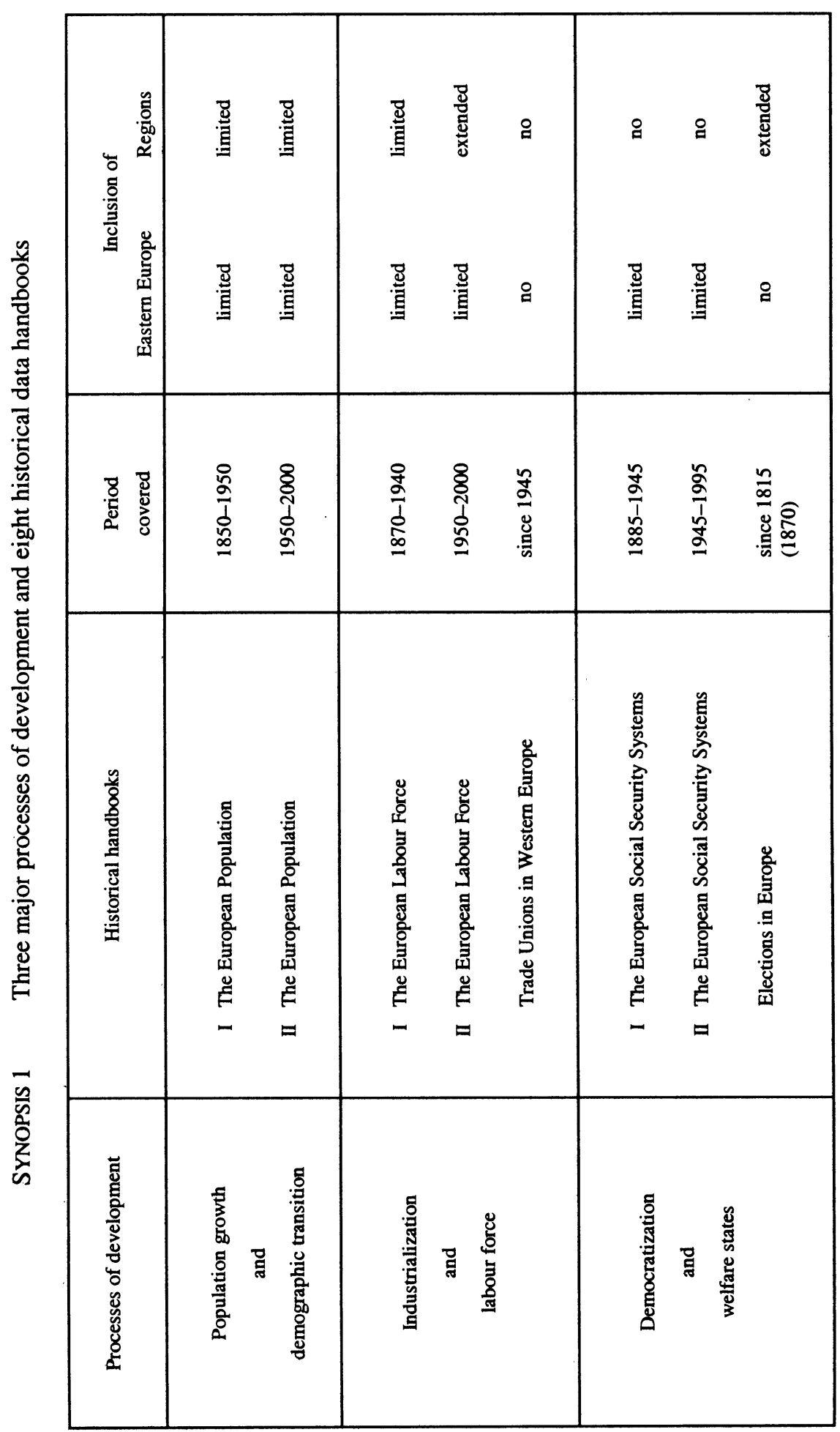


and other surveys. The time period covered is defined by the earliest availability of data. In addition, the volumes will also contain an overview of family law developments in the various countries.

Industrialization is the second major development covered by the handbook series. It can be understood in a broader or narrower sense. In the strict sense, industrialization refers to a process of technological progress used to construct new machinery and to open up new sources of energy, leading to an increase in the productivity of work and the volume of production, and ultimately economic growth. In a broader sense, however, industrialization implies a radical transformation of the social division of labour: between household and workplace, within the newly established enterprises, and between the newly emerging social classes.

It is this transformation that stands in the middle of the two volumes on the development of the labour force in Europe, again divided into one volume for the period until the Second World War, and another for the period after. The data presented come from occupation censuses, usually since the late nineteenth century, and in addition from labour force or other surveys, usually since the 1960s. The volumes and supplementary CD-ROMs provide comparative time series, complex crosstabulations for each census year (such as industry, employment status and sex; sex, age, marital and activity status) and searchable documentation of concepts, definitions and sources.

Until the Russian Revolution, industrialization was identical with the development of industrial capitalism. This implied private property, freedom of contract and free choice of work on the one hand, and the development of national labour markets on the other. For a very long period European societies became 'class societies' in the sense that life chances and living conditions of the mass population were determined by their market position. Class conflict became a predominant political cleavage and gave rise to working-class parties and trade unions everywhere across Europe. The further development was then characterized by varying attempts to institutionalize class conflict' through collective bargaining, the welfare state, and mass democracy.

The development of trade unions usually started in the late nineteenth century, but the institutionalization of industrial conflict and collective bargaining often took much longer. The rush of membership growth mainly occurred after 1945, and today it seems to have already passed its zenith. The great diversity of the national trade union structures, however, is much older and emerged prior to the Second World War: the differences between industrial, occupational or ideological bases of membership recruitment and organization, the varying levels of centralization and degrees of unionization, and more. The handbook on trade unions, which is the second to be published, represents a unique effort to systematically collect data on the membership development of all the main trade unions across Europe from 1945 until today. We hope in the future to be able to supplement this handbook with another on the earlier developments.

The growth of trade unions and the institutionalization of collective bargaining have changed the functioning of the labour market, but they have not reduced its role as the main distributive mechanism in 'class society'. The development of the welfare state instead has introduced a new-political-mechanism. A great variety of public transfer systems and social services has been built across Europe, not only by social democratic and socialist, but also by Catholic, conservative, and liberal 
forces. And all these institutions heavily influence the distribution of life chances and living conditions of the mass population, not completely but relatively independent of market differentiations.

Among the variety of welfare state transfers and services, social insurance, later expanded into social security, was perhaps the major social innovation. Starting in most of Europe during the last three decades before the First World War, it was continuously extended throughout the population and across the continent, and has grown in terms of expenditure to between one-fifth and one-third of GDP today. Again, the enormous growth after the war, especially from the 1960s to the 1970s, has not reduced institutional diversity which originated much earlier: the different bases of entitlement from acknowledged need to insurance contributions to social rights, the varying coverage and differentiation of social risks and population groups, the highly diverse levels of individual benefits and total expenditure, and much more. Within the series, two volumes are dedicated to a detailed institutional and quantitative description of the development of the European social security systems since the late nineteenth century. One volume covers the period up to the Second World War, another the time after 1945.

\section{Elections in Europe Western Europe since 1815-The first volume in the series}

It is difficult to think of the transformation of national states into welfare states without the emergence of urban-industrial societies, above all those of a capitalist nature. At the same time, such a transformation of state functions and structures is hardly conceivable without a preceding or concomitant democratization of the state, of some form of mass participation in the political system.

The institutionalization of elections has been crucial in this respect, and the steps in which the suffrage was extended until it became universal have greatly varied across nations, as have the-majoritarian or PR-electoral systems translating votes into parliamentary seats. With the successive enfranchisement of ever larger population groups, the cleavages existing between them became transfigured into parties and sooner or later stabilized into party systems and voter alignments differing from one nation to the other.

In the present volume, Daniele Caramani traces in detail the development of electoral law in eighteen Western European states and presents the election results (whenever possible) by party for all general elections to the lower houses of parliament since the nineteenth century. There are other handbooks on elections, but the wealth and systematic character of this collection is something new. What makes it really unique, however, is the disaggregation of election results by constituencies and/or other sub-national units. This has raised the number of election results to a much higher power; for the first time, it has become possible to systematically investigate the territorial structuring of the vote across Europe.

The development of the nation-state has had a standardizing effect on the underlying society, to be sure, and there has been a tendency of territorial cleavages to give way to 'functional' ones cutting across the whole territory. However, this tendency as well as standarization have been far from complete. As mentioned above, the historical overlaying of ethnic-linguistic, religious, economic, and political 
boundaries has created a varying internal heterogenity which largely persists until today.

The volume by D. Caramani opens ways for studying the territorial structure of the European nation-states. I wish we could have done more in this direction also in the other volumes (see Synopsis 1). This will remain a major task for the future (as will the use of cartography). The main reason for this lies in the fact that in speaking of the 'European societies' we cannot simply identify them with the 'societies of the nation-states'.

\section{Notes on the prehistory of the handbook series}

This series of historical handbooks has had predecessors: two volumes which we published in 1983 and 1987 under the general title State, Economy, and Society in Western Europe 1815-1975 (Frankfurt: Campus; London: Macmillan; Chicago: St. James). To produce these earlier volumes, since the 1970s we have built up our own data archive with funds from the Volkswagenstiftung. When in 1989 I became founding director of the Mannheim Centre for European Social Research, I brought this archive, now named EURODATA Research Archive, into the new institution.

It has been the explicit goal of this archive to contribute to a Europeanization of the social science data base. We have sought to develop such a contribution, always in co-operation with institutes throughout Europe, in three directions:

1. by developing a European social reporting system (with a family policy databank as a first component);

2. by regionalizing data (with the hope of eventually producing a historical regional atlas of Europe);

3. by producing, on a completely new basis, another series of historical handbooks for the comparative-historical study of European society.

Compared to our earlier efforts, of course, the technological possibilities have been greatly improved. We have therefore included with each of the volumes a CD-ROM which contains much more information than the volumes and which should be easily used for purposes of data analysis. In this way we hope to make a major contribution to improving the European data base which will remain a collective task. 


\section{Preface and Acknowledgements}

This handbook presents the collection of results of national elections to the lower houses of 18 European countries beginning with 1815 in the earliest case and ending with the most recent published election. The election returns have been collected at the level of the single constituencies; for this reason they are not entirely presented in printed form in this handbook (which would take thousands of pages) but instead have been made available in full on CD-ROM.

The handbook can be regarded both as an independent product, useful for consultation in its own right apart from the machine-readable data stored on the CD-ROM, and as a guide to the results. The documentation collected and arranged in the different country chapters permits the most profitable use of the data stored on CD-ROM. In order to make the data fully comprehensible, for each country the documentation includes the evolution of the electoral systems as well as the trajectories towards the democratization and equalization of voting conditions. The documentation also contains information on political parties, constituency changes, and the official and secondary sources on elections.

While a large number of handbooks on electoral laws and electoral systems are available (see the Introduction below), a thorough and standard collection of disaggregated electoral results is still missing. The only comparative and historical data handbook on elections is that of Mackie and Rose (1991, third edition). Unlike their work, however, this collection includes data collected at the level of single constituencies and/or other sub-national units, and incorporates additional information. Furthermore, all data have been computerized. For the first time the results of the elections held in 18 European countries are brought together according to standard rules making it possible to increase progressively both the quantity and quality of data (by covering new countries, in particular Eastern Europe which, to my regret, I was not able to include in this work).

The work of collecting and documenting European electoral data presented here developed jointly with the comparative research on the formation processes of national electorates in Europe carried out in the framework of a Ph.D. dissertation, first started at the University of Geneva in 1993, written from 1994 to 1996 at the European University Institute of Florence, and finalized at the Mannheim Centre for European Social Research (Mannheimer Zentrum für Europäische Sozialforschung, MZES) of the University of Mannheim.

This study required geographically disaggregated data from the earlier periods of modern elections and party systems. In this regard, the data that were machinereadable in existing databases (rare also on a national scale) turned out to be fragmented, often limited to the most recent periods, poorly documented, and characterized by an extremely low degree of comparability since data collectors only rarely referred to similar principles of data gathering. 
This was the impetus for starting a standardardized and systematic collection of election results accompanied by thorough documentation. This project, which developed into a large amount of material, was carried out at the Mannheim Centre from 1996 to 1999 and transformed into this book and the accompanying CD-ROM.

In preparing this volume and CD-ROM, I am indebted to many persons. However, any errors that may appear in this volume are entirely my own responsibility.

I would like to begin by expressing special thanks and sincere gratitude to Stefano Bartolini of the European University Institute in Florence, especially for all that he gave me as a teacher and friend, and for his amicable and proficient guidance in the early phases of my university life. His approach to empirical comparative and historical research has had an enormous influence on my own academic development as it has on so many of his students. I started the present project when I was one of his graduate students in Geneva and continued later at the European University Institute. Bartolini encouraged this project which would not have been possible without his constant advice and support.

Several colleagues and friends have helped me collect data and information. I would like to thank Birgitta Bader-Zaar of the University of Vienna for her help with the elections under the Habsburg monarchy; Riitta Kyllönen for her help with the Finnish language, Ann-Christina Lauring Knudsen of the European University Institute in Florence for her help in reading Scandinavian languages; José Ramón Montero and Marta Peach of the Juan March Institute in Madrid for their help in retrieving Spanish data; the researchers of the Norwegian Social Science Data Archive in Bergen for the publications of Norwegian results; Tuija Meisaari-Polsa of Swedish Statistics for her help with nineteenth century Swedish elections; Maria Serena Piretti of the University of Bologna for her help in retrieving Italian publications of electoral results; and Christos Tsimpos of the University of Athens for providing me with Greek data. I would like to extend my thanks to those persons working in the various archives, libraries, ministries, and national statistical offices who provided me with data and whose names are too numerous to be listed here. They do an indispensable service for empirical social sciences through their expertise and efficiency.

Several experts read the single country chapters, and I am very grateful for their comments: Bernt Årdal of the Institute of Social Research in Oslo, Birgitta BaderZaar of the University of Vienna, Jørgen Elklit of the University of Arrhus, Gretar Eythorsson and Mikael Gilljam of the University of Göteborg, Michael Gallagher of Trinity College (Dublin), Ólafur Th. Hardarson of the University of Iceland, Helge O. Larsen of the University of Troms $\varnothing$, Paul Lucardie of the University of Groningen, Peter Mair of the University of Leiden, Wolfgang C. Müller of the University of Vienna, Serge Noiret of the European University Institute, and Jan Sundberg of the University of Helsinki.

I wish to express my immense gratitude to all the colleagues and friends at the MZES, where I spent more than two years, beginning with Peter Flora for giving me the unique opportunity to carry out the project at such an excellent institute for comparative social research. I thank him especially for trusting and giving a chance to a young student embarking on an adventurous project. I thank him also for his personal engagement in finalizing the manuscript, with his painstaking attention to the smallest details, from the formatting of graphics to discovering typographical errors. 
His sharp critiques and congenital dissatisfaction were a constant challenge through all phases of the project. To my despair, he totally reshaped (and rewrote) most of the introductions in the last weeks before completion. I thank him for that now.

I am also grateful to my colleagues at the EURODATA Forschungsarchiv of the MZES Franz Rothenbacher and Marianne Schneider for their friendly collaboration during my stay in Germany, as well as to Gretchen Wiesehan for what has been not only excellent English proofreading but much more a critical review of the contents of each chapter. Many thanks also to Marlene Alle and Christian Melbeck of the MZES computing centre for their technical support during all the phases of this work. Birgit Becker did the remarkable work of making the CD-ROM and I wish to thank her, as well as the other student assistants (Marçel Emami and Christian Knust), for the time and effort they devoted to it. I thank also Reinhart Schneider, the managing director of the MZES, for his genuine interest in my work and the organizational support.

Most of all I would like to express my gratitude to Franz Kraus, the managing director of the EURODATA Forschungsarchiv. Franz spent months, including evenings and week ends, working on the original datasets to transform them into the large amount of useful material now available on CD-ROM. This proved to be extremely challenging in technical terms, and I am sure there are not many people able to do what he has achieved. In addition, he guided each phase of the production of the CD-ROM and has been a continuous source of ideas and suggestions for improving the product. Without his great technical expertise in data management and constant readiness to help, this book and the CD-ROM would not have been possible. The fact that he did all this with his usual good spirits will be no surprise to those who know Franz.

Working with these people has been a great experience. The colleagues and friends at the MZES have devoted an invaluable amount of time and energy to make this handbook possible. I would like them to know that at no moment have I taken this for granted and that I am deeply grateful. 


\section{Table of Contents}

Editorial Introduction by Peter Flora

Page $v$

Preface and Acknowledgements

$x v$

List of Printed Tables

$x x$

List of Figures

Abbreviations and Symbols

$x x i i$

xxiii

Introduction

1

PART I ELECTIONS IN COMPARISON

$1 \quad$ Electoral Laws and Systems

21

2 The Institutional Development of Elections in Europe

The Territorial Structuring of the Vote in Europe

\section{PART II COUNTRY CHAPTERS}

1

Austria

Belgium

149

3

Denmark

191

4

Finland

251

5

France

291

6

Germany

375

Greece

461

7

Iceland

517

9 Ireland

547

605

10 Italy

675

11 Luxemburg

697

12 Netherlands

737

13 Norway

777

14 Portugal

799

15 Spain

857

16 Sweden

905

17 Switzerland

945

18 United Kingdom

PART III APPENDICES

1 The Data on CD-ROM

2 A Note on Election Statistics

4 Secondary Literature 


\section{List of Printed Tables}

Tables are numbered according to chapters.

\section{INTRODUCTION}

1 Dates of first election collected and number of elections by country 4

2 Availability of electoral data by territorial units 7

3 Correspondence between electoral and administrative units 4

$4 \quad$ Availability of election results by party at constituency level or other sub-national level $\quad 10$

5 Codes for political parties and party labels 11

6 Subdivision of electoral results between handbook and CD-ROM 13

\section{PART I ELECTIONS IN COMPARISON}

1.1 Hypothetical distribution of seats with natural quota 34

1.2 Hypothetical distribution of seats with Droop quota 34

1.3 Hypothetical distribution of seats with modified quota 35

2.1 Electoral systems in Europe: 1815-present 48

2.2 The transition to general parliamentary representation 52

2.3 The introduction of universal suffrage 53

2.4 Abolition of voting restrictions and plural vote 55

2.5 The lowering of the voting age (1910s-1990s) 57

2.6 The introduction of direct elections 58

$\begin{array}{lll}2.7 & \text { The introduction of PR } & 60\end{array}$

2.8 Compulsory voting 63

2.9 The introduction of secret voting 65

3.1 Territorial heterogeneity: party support and turnout, 1848-1998 71

3.2 Territorial heterogeneity over decades: $1830 \mathrm{~s}-1990 \mathrm{~s}$ (party support and turnout) 73

3.3 Levels of territorial heterogeneity by countries (party vote): 1918-present 75

3.4 Levels of territorial heterogeneity by country (turnout) 77

3.5 Territorial heterogeneity of party support by country in three different periods

3.6 Levels of territorial heterogeneity by religious and linguistic fragmentation (standard deviation)

3.7 Levels of territorial heterogeneity by territoriality of cleavages (standard deviation)

3.8 The impact of social changes on the levels of territorial heterogeneity (standard deviation) 
3.9 The territorial heterogeneity of party families in Europe over the entire period

3.10 Party families by levels of differences of heterogeneity across countries (index of variation)

3.11 Territorial heterogeneity of European socialist, social democratic, and labour parties

3.12 Territorial heterogeneity of European liberal and radical parties 91

3.13 Territorial heterogeneity of European communist parties 92

3.14 Territorial heterogeneity of European Catholic, inter-confessional, and Protestant parties

3.15 Territorial heterogeneity of European agrarian and peasants' parties $\quad 94$

3.16 Territorial diffusion of European regionalist parties

\section{PART II COUNTRY CHAPTERS}

Each country chapter contains text tables, Synopses, and tables of Election Results (selections from the results stored on CD-ROM). They are listed at the beginning of each Country Chapter. There are always six Synopses which may be further subdivided by period.

Synopsis 1 Development of electoral law

Synopsis 2 Dates and type of elections

Synopsis 3 The [Country] party system tree

Synopsis 4 Political parties

Synopsis 5 Available information by levels of aggregation

Synopsis 6 Territorial units

The number of Election Result tables varies from chapter to chapter. The complete collection of results in absolute figures, percentage distribution by parties and by constituencies is available on CD-ROM.

\section{PART III APPENDICES}

A.1.1 Overview on the availability of data and organization of the files on CD-ROM

A.1.3 Variable names, variable lables; values, and value labels 


\section{List of Figures}

\section{PART I ELECTIONS IN COMPARISON}

3.1 The reduction of territorial heterogeneity of party support and turnout in Europe: 1840s-1990s (standard deviation)

3.2 The evolution of territorial heterogeneity of party support by country: 1832-present (standard deviation)

3.3 Evolution of territorial heterogeneity of support for main party families in Europe: 1848-present (index of variation)

3.4 The evolution of territorial heterogeneity of inter-confessional, Catholic, and Protestant parties: 1848-present (index of variation)

3.5 Number of uncontested constituencies for Conservatives, Liberals, and Social Democrats in Denmark: 1849-1913

3.6 Percentage of uncontested constituencies for Conservatives, Liberals, and Labour in Great Britain: 1832-1935

3.7 Presence in constituencies of political parties in Great Britain: 1832-1935

3.8 Presence in constituencies of political parties in Denmark: 1849-1913 


\section{Abbreviations and Symbols}

LIST OF ABBREVIATIONS

HB Hagenbach-Bischoff formula

LR-Hare Largest-remainders Hare or simple quota formula

N.a. Not available

PR Proportional representation

STV Single transferable vote

Unc. Uncontested (unopposed) constituency

LIST OF SYMBOLS

- Not applicable

... Data not available (missing) 